\title{
Refugee Camp Security: Decreasing Vulnerability Through Demographic Controls
}

\author{
RICHARD A. I. JOHNSON \\ Department of Political Science, University of California, Davis, One Shields \\ Avenue, Davis, CA 95616 \\ rajohnson@ucdavis.edu
}

MS received October 2009; revised MS received August 2010

\begin{abstract}
In the past, refugee camp security has been examined in many lights; however, the demographic make-up of camps has not been focused on. In this article, I present a quantitative model that examines attacks on refugee camps. I argue that the likelihood of an attack on a camp is affected by the demographic make-up of the camp. The primary demographic causes that affect vulnerability are the level of male population of the camp, age of camp residents, and the size of the camp. With the available data, I find that these demographic indicators are significant in determining the likelihood of an attack. Assessing what characteristics of camps and their populations increase the likelihood of an attack should serve as a guide to the implementation and organization of new refugee camps to ensure peace and stability for an already fragile community.
\end{abstract}

Keywords: refugees, camps, militarization, security

\section{Introduction}

Refugee flows occur because 'the basic bond between citizen and government has been broken' (Stein 1986: 269). Historically, refugees are typically from rural areas and flee to neighbouring low-income states, creating a financial burden on the host state (Ferris 1985; Stein 1986; Gorman 1987). The outcome is a prevalence of refugee camps where host states are responsible for providing physical security for the refugees. One problem, however, is that host states are not always willing to provide adequate security or capable of doing so (UNSC 1998; Achvarina and Reich 2006), making the refugee camp vulnerable to attack. As of 2006, there were about 10 million refugees and 13 million internally displaced persons (IDPs) in the world; in Africa alone there were 3.1 million refugees (African Development Bank 2009). These numbers highlight the magnitude of the refugee crisis and the importance of providing security to an endangered population. 
Despite refugee camps largely being provided with less than adequate security, not all camps suffer from attacks. This article examines the behaviour of armed groups and the vulnerability of refugee camps. The previous qualitative and case study literature provides explanations linked to politics, ethnicity, and security as factors linked to refugee camp militarization. This article focuses instead on the demographic make-up of camps. The theory developed is based on lateral pressure theory, developed by Choucri and North (1975), which argues that if a state is lacking the necessary resources to support the population, governments will be pressured to take actions beyond their borders, which may lead to conflict with other states. Moving beyond the lateral pressure theory, the hypotheses are constructed using an opportunity and willingness framework similar to Most and Starr (1989) and Siverson and Starr (1991). The theory and framework are adapted from state behaviour to apply to sub-state actors.

Building on the arguments of Weinstein (2007), I show that the expected behaviour of rebel groups suffering from lateral pressure is applicable to other types of armed groups. I argue that armed groups attack refugee camps due to lateral pressure caused by a lack of material and/or natural resources in their area of origin, which are necessary for survival. To survive, armed groups need access to arms and ammunition, new recruits, and material resources to provide food and finances for the members (Weinstein 2005, 2007). Armed groups achieve their needs through patronage from third parties, cooperation with civilian populations, conflict with civilian populations, and using available natural resources (Weinstein 2007). Groups using coercive tactics against civilians may soon find themselves lacking a population to exploit, due to flight of the civilians. When civilians flee, one alternative is for armed groups to attack refugee camps that the civilians fled to.

Refugee camps are attractive targets because aid organizations provide camps with food and other goods, while host states are not always willing or able to provide adequate security (UNSC 1998; Achvarina and Reich 2006). In addition, refugee camps are typically located in poor rural areas far from the host country's capital (Gorman 1987). The result is refugee camps in possession of desirable goods, but without the means to protect them. This combination makes refugee camps attractive targets for armed groups seeking to increase their capabilities. However, not all refugee camps are equally vulnerable.

To determine the vulnerability of refugee camps I use an opportunity and willingness framework to argue the demographic make-up of camps directly relates to the likelihood of an attack. As demographics within the camps shift, so does the expected payoff of armed groups due to increasing or decreasing costs. To test my arguments statistically, I use three demographic indicators of camps as proxies for vulnerability: gender distribution, age distribution, and population size. I find that gender, age, and population are 
significant factors in predicting attacks on refugee camps under varying circumstances in host and home states of refugees.

The study is a significant contribution to the refugee camp security literature for several reasons. First, although the argument that more vulnerable refugee camps are more likely to face attacks is not groundbreaking, the measurement of vulnerability through demographics is unique. Further, I am applying political science theory to refugee security, in line with suggestions by Black (2001), in order to make generalizable arguments applicable not only to armed groups, but also to militarized refugees and internally displaced populations. In addition, lateral pressure theory could be used to explain refugee flows in the future. Lastly, the article highlights the necessity for additional collection and distribution of data related to characteristics of individual refugees and refugee camps in order to make specific policy recommendations concerning refugee security.

The next section defines key terms in order to clarify the arguments further on. The definitions are followed by a review of the relevant refugee literature, focusing on the origins of armed groups and refugee camp security. I then present my lateral pressure theory, followed by the opportunity and willingness framework, in order to set up the research design and empirical test. The article closes with a discussion of the implications of the findings and extensions to pursue in the future.

\section{Defining 'Refugee Camp Militarization', 'Resources', and 'Security'}

This article argues a theory of refugee camp militarization based on the necessities that people have for resources and security. However, these terms need clarification as they often have different meanings under different circumstances. First, 'militarized refugees' and 'refugee camp militarization' are two different phenomena. Second, 'resources' can come in various forms, such as natural or material. Third, the provision of security by the state or international aid organizations can occur under different circumstances. The importance of these terms requires specific definitions for their use in this article.

\section{Militarization}

Within the literature are conflicting definitions for what constitutes a militarized refugee camp. The lack of a clear definition suggests that researchers may not be using consistent criteria to classify or differentiate militarized refugees versus militarized refugee camps (see Muggah and Mogire 2006). Muggah and Mogire (2006) put forth a clear separation between the types of militarization. Refugee camp militarization refers to attacks on the camps or the presence of armed elements that are not refugees (including forced recruitment), while militarized refugees refers to the refugees of the camps openly taking up arms. However, the current authority on refugee camp 


\section{Richard A. I. Johnson}

security, the Ford Institute, refers to refugee camp militarization as the presence of armed groups inside the camps. Due to conflicting terminology and my focus on attacks on camps, I use the term 'armed attacks' to refer to attempts by outside forces to militarize camps through attack or forced recruitment and 'refugee militarization' or 'militarized refugees' to refer to refugees taking up arms.

\section{Resources}

The differentiation between material and natural resources is important because civilians, refugees, and armed groups need access to one or the other or both. I define 'material resources' as finished goods that can be provided to civilian populations by aid groups or governments. These items could be food, medicine, mechanical equipment, etc. (Jacobsen 2002). Thus, if armed groups are attacking refugee camps for economic benefits, it is because the armed groups wish to take the material resources refugees and aid groups may possess.

On the other hand, natural resources have multiple categories. Some natural resources are directly usable by civilians or refugees, which include cropland, fresh water, forests, and fisheries. Other natural resources are available for use by highly organized groups or the state, such as gemstones, precious metals, and oil (Homer-Dixon 1994; Ross 2004; Urdal 2005; Weinstein 2007). Income from the natural resources the state benefits from can be used to provide material resources to civilians living in areas that may be lacking natural resources. Lastly, there are natural resources that are lootable, which are defined as 'lucrative, easy-to-transport resources', such as alluvial diamonds and tropical timber (Snyder 2006: 943-4). Organized groups can take advantage of lootable resources in order to fund their activities.

\section{Security}

While 'security' is traditionally discussed in terms of states using their militaries to protect territory, there has been a shift to the concept of 'human security' by the United Nations. Human security is a broad term that encompasses many subcategories of security, including economic, food, health, environmental, personal, community, and political (UNDP 1994). However, refugee camps present a unique situation: host governments and aid groups share the responsibility for the provision of security and material assistance (Pitterman 1985). Often the host state is unable or unwilling to provide adequate physical security for refugee camps (UNSC 1998; Achvarina and Reich 2006), whereas aid organizations typically provide care and assistance, as opposed to physical security, to refugees (Pitterman 1985). Despite differing types of security and responsibility, the primary concern regarding security in this paper is the physical threat of attack that refugees face. 


\section{Literature Review}

A wide range of refugee literature exists; for this paper, two subcategories are brought together to lay the groundwork for my theoretical contribution. First, I examine the existing literature on refugee camp security. This literature shows why refugee camps are vulnerable targets for attacks by armed groups. Second, I draw on the literature examining the behaviour of armed groups. Differing motivations of armed groups may lead to different expectations about attacks on refugee camps.

\section{Refugee Camp Security}

Reducing vulnerability at refugee camps is important because the causes of refugee flows are rarely short term and the three 'durable solutions', resettlement, integration, and repatriation (Stein 1986; Gorman 1987; Crisp 2003), have become more difficult to accomplish over time. Voluntary repatriation is the ideal solution for refugees and host states, while refugee resettlement in third countries or integration into host communities can reduce the financial cost for host states and provide greater stability for the refugees than camps. However, resettlement and integration have become less popular over time, as states began to view refugees as economic and environmental burdens, as well as potential security threats (Rogge 1981; Stein 1986; Mandel 1997; Barnett 2002; Adamson 2006). In addition, during the post-Cold War era, major powers no longer view refugees as pawns to be used strategically and they are less welcome in rich and powerful states. The result has been a shift in UNHCR operations from promoting asylum to conducting large-scale humanitarian operations to prevent refugee flows or regionally containing them (Hammerstad 2000). The lack of opportunity for resettlement and integration, and the illegality of forced repatriation (though it occasionally occurs), result in large numbers of 'protracted refugees', who have lived in camps for over five years with no immediate expectation of a durable solution occurring (Stein 1986; Crisp 2003: 114). Because many refugees live in camps for long periods, their physical security is an important topic.

The UNHCR guidelines for refugee camp security promote three different levels of security: soft, medium, and hard, which have become known as the 'Ladder of Options' (1999). Physical security is necessary to prevent external attacks, as well as internal conflicts and refugee militarization. While it is the host state's responsibility to provide physical security for refugee camps (UNHCR 2000), many are not willing or able to take on the responsibility (UNSC 1998; Stedman 2003; Achvarina and Reich 2006). The current lack of security makes women and children vulnerable to banditry and men fearful of forced recruitment (UNHCR 1999). Thus, the 'medium' and 'hard' options involve the deployment of police forces or military by the international community, as opposed to the host state; however, these options are extremely expensive. Beyond UNHCR providing physical security to ensure safety, the Ladder of Options illustrates ways refugees and aid groups can take 
preventative actions in a 'soft' manner to enhance security in the lower two rungs, such as social cohesion and camp location/size.

Social cohesion inside and outside a camp can help provide stability and security. One way to create cohesion within camps is for the refugees to elect leaders and representatives to promote the humanitarian aspects of the camp (UNHCR 1999). However, the elected leaders should remain symbolic, leaving the distribution of material resources to humanitarian agencies to prevent corruption (UNHCR 1999; Lischer 2005). To produce social cohesion outside the camp between refugees and host communities, Martin (2005) believes increasing the interaction between, and education of, refugees and host communities can construct relationships between the groups that are cooperative rather than conflictual. Despite the possibilities, the overall lack of host states providing physical security could nullify the effectiveness of these options. However, the social options could be more effective if combined with other preventative factors to increase both physical and human security.

The primary preventative factors taken to increase refugee camp security are size and location (UNHCR 1999). UNHCR (1999) prescribes that the maximum size of a refugee camp should be 20,000 residents; however, many are larger than recommended. This provision's intent is to help reduce armed attacks against camps and the militarization of refugees within the camp by having a manageable number of refugees. Along with the overall size, the camps should be located at a 'reasonable' distance from the border (Metcalfe 1970; UNHCR 1999: 3; Carik 2008), the intention being that armed attacks by outside forces will be more difficult and militarized refugees will find it harder to conduct cross-border raids. However, a minimum distance of camps being located $50 \mathrm{~km}$ from the border does not seem to deter attacks (Reich 2008). This may be because the armed groups attacking the camps are local. Overall, the 'Ladder of Options' put forward by UNHCR is a good start if these options are actually implemented in the field. However, as the report notes (UNHCR 2000), if the host state does not provide protection security achieved through third party providers is extremely costly. Thus, other possibilities for producing camp stability need to be taken into account.

\section{Armed Attacks on Refugee Camps}

In general, armed attacks on refugee camps occur for one or more of four reasons: environmental conflict, looting, forced recruitment, and politicide or genocide (Mtango 1989; Blavo 1999; Türk 2003). Depending on the type of armed group - angry local citizens, rebels participating in a civil war or simple bandits - the goals and level of violence of the attack can vary (Mtango 1989). Though the type of group attacking and their goals may vary, the underlying motivations are linked to natural or material resource allocation among the different types of groups.

Competition between the local residents and the refugees over access to natural resources can lead to 'environmental conflict' (Blavo 1999; Goldstone 
2001; Jacobsen 2002). When refugees come into an area, they begin using local natural resources. If there are not sufficient natural resources in the area or material resources being provided to support the influx of refugees, disputes may arise between refugees and local residents (Goldstone 2001). Refugees can be viewed as 'exceptional resource users' compared to the local population (WCED 1987). When it comes to using natural resources, the local population is risk averse because they have a longer time horizon (i.e. they have longer history of living in that area). In contrast, refugees consider themselves temporary residents and are in dire straits. Therefore, refugees are risk acceptant when it comes to using large amounts of natural resources. For example, when there is a limited supply of water or firewood, refugees do not necessarily conserve usage, leading to increased instability for the local population and the possibility of environmental conflict.

However, other scholars argue that resource scarcity is not sufficient on its own to cause conflict between refugees and a local population (Black 1998; Lischer 2005; Martin 2005; African Development Bank 2009). Martin (2005) moves beyond the previous scarcity arguments to posit that elites socially construct environmental conflicts between the host communities and refugees in order to manipulate local political outcomes. Those who control the distribution of resources possess the greatest amounts of power. This argument also applies within the refugee camps; leaders controlling the distribution of resources can manipulate activity within a camp (Lischer 2005). Thus, environmental conflict can lead to violence when there is a perceived lack of natural resources and group leaders find it advantageous to manipulate the situation. If this manipulation occurs, then in many ways these attacks are not much different from looting.

Armed groups attack and loot camps for material resources when they do not have sufficient economic endowments to accomplish their goals (Jacobsen 2002; see Weinstein 2007). For bandits, the goal of looting may be to increase their personal wealth or to provide for their own group outside of the refugee camps. For rebels, looting provides material resources, such as food or goods tradable for arms or ammunition. Without looting, whether it is from civilians or refugee camps, many groups find it much harder to survive. On the other hand, rebel groups economically endowed by third-party financiers or natural resource-rich environments, do not need to use coercive tactics against civilian populations to survive, but are also not reliant on cooperative interactions for survival (Weinstein 2007). Thus, in the case of wealthy groups, the use of coercive tactics against civilians and refugees is for other reasons, such as forced recruitment, politicide, or genocide.

Forced recruitment occurs because armed groups need additional labour in order to pursue their objectives. Often, forced recruitment involves removing children from refugee camps (Achvarina and Reich 2006; Alfredson 2002). Achvarina and Reich (2006) argue that the number of child soldiers in armed groups is a direct result of vulnerable refugee camps. In other cases, host governments look the other way as rebel groups from other states recruit 
large numbers of refugees to go home and fight (Stedman 2003; Milner 2005). For example, in 2000, government forces allowed Liberians to recruit forcibly from camps in Guinea (Milner 2005). Alternatively, armed groups may infiltrate refugee camps to recruit new fighters without force, by promising benefits in the future (Achvarina and Reich 2006). The possibility of subtle recruiting leads to an overall underestimation of the number of incidents of recruitment from refugee camps; however, subtle recruitment does not involve an attack on a camp.

Though looting and forced recruitment have basic motivations relating to gaining resources, the motivations for attacks on a refugee camp to commit politicide or genocide are complicated. In politicide, the targets are chosen due to their political ideology, status in the political hierarchy, or role in the political opposition to the group in power (Harff and Gurr 1988). In genocide, the targets are chosen based on ethnicity, religion, or nationality (Harff and Gurr 1988). The difference between genocide and politicide, then, is the way perpetrators identify the targets; however, their primary means to achieve goals, mass killings, are the same (Fein 1993; Harff and Gurr 1988). A similar motive is to instil enough fear into the refugees that they will choose to remain in camps in protracted situations, even after a conflict ends. The Janjaweed militias in Sudan are a current example of armed groups attacking refugee camps for politicide/genocide. The Janjaweed receive direct support from the Sudanese government, making them an economically endowed armed group, which means they can pursue their goals without regard for the opinion of civilians (see Weinstein 2007).

The review of the motivations for armed attacks on refugee camps explains the goals of armed groups, but does not detail the underlying motives of lateral pressure. Armed groups take action against refugee camps because of an overall lack of natural and material resources necessary for survival. In order to gain material resources, armed groups can attack refugee camps. I argue the decision-making process relates to the perceived vulnerability of the refugee camps. Armed groups want to minimize the amount of risk they are taking to achieve their goals.

\section{Theory of Lateral Pressure}

I draw on the theory of lateral pressure to provide a framework for understanding the patterns of attacks on refugee camps. Lateral pressure refers to 'the process of foreign expansion of any activity' to increase capabilities in order to provide the population with additional services (Choucri and North 1975: 16). In order for a group's actions to qualify as lateral pressure, three aspects of a foreign expansion must be identifiable: the situation motivating activity beyond borders, the activity beyond borders, and the impact of these activities on the people of another state and their environment. The three aspects in my application of the theory are a) natural or material resource gain, b) attacks on refugee camps, and c) the impact of attacks on the 
refugees. While I directly discuss the situation motivating armed groups to move outside their borders, building on the arguments of Weinstein (2007), I only test the activities of armed groups (attacks on refugee camps) beyond their borders using the opportunity and willingness framework. Though only the second step is necessary for testing, the first step shows how the test does not require information on which type of armed group attacked the refugee camp, thus making the theory more generalizable.

Originally developed as an explanation of state behaviour in the international system, the theory of lateral pressure is applicable to sub-state group behaviour. Sub-state groups, as well as states, require material and/or natural resources in order to support their populations; however, the population of sub-state groups is much smaller. When groups do not produce or receive the necessary resources for survival, they must move beyond the borders of their traditional area of operation, whether it is a town, region, or country. However, when moving beyond their 'borders' seeking to gain capabilities, groups may cross the 'borders' of other groups. When groups cross each other's paths, the opportunity for interaction occurs and can be cooperative (trade) or conflictual (armed violence). I focus on conflictual interactions between armed groups and refugees housed in camps.

Due to the focus on interaction between armed groups and refugee camps, and there being different types of armed groups, a discussion of armed group behaviour is necessary. Based on the work of Weinstein (2007), I expand the argument to other types of armed groups, whether they are angry local citizens, international or domestic rebels, bandits, ${ }^{1}$ or refugees. Depending on the type of armed group, the possible goals differ. Local groups (angry citizens, bandits, or rebels) have five typical goals: response to environmental conflict, looting, forced recruitment, politicide or genocide. International groups (bandits or rebels) have four typical goals: looting, forced recruitment, politicide, or genocide. Refugees staging attacks on refugee camps have one typical goal: looting. Though the groups are inherently different, I argue, using Weinstein's theory, that motivations of the over-lapping goals are similar across groups and relate to the distribution of material and natural resources. In addition, I discuss the general expected payoffs and timelines of the goals. Because I show the similar expectations in the motivations for an attack, the internal structure of armed groups, such as the specific goal and type of armed groups, does not need to be known for this project.

Thus far, I have identified five goals of armed groups' attacks on refugee camps: response to environmental conflict, looting, forced recruitment, politicide, and genocide. All of these goals allow armed groups to gain capabilities they perceive as necessary to survive and have direct and indirect underlying motivations. The direct motivation behind environmental conflict is the perceived lack of available natural resources to share between local populations and refugees housed in camps. The indirect motivation for attack is that the government is not providing material resources to local residents as a substitute for sharing the natural resources in areas around camps. 
An attack due to previous environmental conflict has an immediate, small to medium sized payoff for the attacking group, depending whether the attack prevents future refugee use of local natural resources.

For looting, the direct motivation for militarized refugees, local, or international groups also relates to a lack of resources (material, natural, and lootable). For militarized refugees, looting occurs due to a perceived lack of distribution of material resources from aid groups and/or the lack of opportunity to pursue economic activities in the host state. For local groups, looting occurs due to a lack of natural resources for survival, in conjunction with the government not providing material resources as 'welfare'. In addition, local groups are not eligible to receive material resources from aid groups providing for refugee camps. Foreign groups consisting of bandits or rebels loot because they can no longer survive by taking predatory action against civilians in their area of origin, possibly because they created the refugee flow to begin with. In addition, the lack of lootable resources in their area of origin could push the armed groups across the border seeking material resources. Looting has an immediate small payoff of whatever material resources the attacking group can garner.

Forced recruitment is typically done by local or foreign rebel groups (though government sponsored groups may also recruit forcibly). For both types of groups, forced recruitment is necessary because their economic endowments do not allow for recruitment through the use of promised payment. Beyond not possessing the ability to pay voluntary recruits, groups recruiting forcibly are not able to use an 'activist' strategy to encourage voluntary recruitment with a long-term payoff (Weinstein 2007). On the other hand, economically endowed rebels may forcibly recruit, but do not have to, thus they may not accept the reputation cost of attacking refugee camps. Groups that have to recruit forcibly will most likely be motivated by the opportunity to loot. The payoff from forcibly recruiting refugees does not occur immediately; armed groups must train these new recruits in order to generate value for the armed group.

To commit politicide or genocide, foreign groups must be extremely motivated. These groups are acting with the expectation of a future payoff in material or natural resources in the home state of the refugees they are attacking. Indirectly, the state-sponsored groups engaging in politicide or genocide are taking action to ensure their political or ethnic group retains power in their home state. Taking these extreme actions helps to reduce future political competition, based on the assumption their groups will win the civil conflict occurring in the home state. For groups committing politicide or genocide the payoff timeline can be large. As stated above, for a payoff to occur their group needs to win the civil conflict in their home state, otherwise the armed group may receive nothing. If successful, however, the payoff could be large and long-term.

Up until this point, I have identified the motivations and payoffs of armed groups that attack refugee camps, which leaves one question remaining. 
How can refugee camps be made safer from attack? Refugee camps can be made safer if the cost of an attack is more than the expected payoff for armed groups. To examine the costs of attacking a refugee camp, I apply an opportunity and willingness framework to show how shifting demographic factors can affect the decision-making of armed groups.

\section{Opportunity and Willingness}

To test the vulnerability of camps, I employ an opportunity and willingness framework to show how the demographic make-up within camps affects the likelihood of attack. Opportunity refers to the macro-level factors affecting vulnerability, such as geography and camp location. Willingness refers to the micro-level factors affecting the decision-making process of armed groups, such as camp demographics and level of physical security. Previously, the opportunity and willingness framework has been used to investigate international war initiation and diffusion (Most and Starr 1989; Siverson and Starr 1990, 1991) and is applicable here because I use the framework to investigate the diffusion of violence by sub-state actors. The first step is to examine the opportunity of armed groups; if opportunity exists, the cost and benefits of attack temper or enhance the willingness level.

Environmental and structural factors determine opportunity at the macro level. Opportunity is the 'possibility of interaction' between actors (Most and Starr 1989: 30). Interaction between actors must be intellectually, physically, or technologically possible for opportunity to be present (Siverson and Starr 1990). In my application, the actors are the refugees in camps and the armed groups attacking the camps. Thus, the opportunity for attack exists if armed groups have the capability of attacking the refugee camps. Factors such as how the attacking group travels (e.g. foot, horse, truck) have a direct impact on the possibility of an armed attack on a camp. In turn, the terrain located between the camp and areas from which militarizing groups originate affects the opportunity of interaction, and thus, the vulnerability of the camp.

Willingness refers to the micro-level choices of individuals or groups (Most and Starr 1989). An armed group's willingness to attack a refugee camp is determined by examining the costs and benefits of an attack (Siverson and Starr 1990), which comes from two sources. First, the benefits of attacking a refugee camp stem from the goals of the armed group. Second, willingness is related to the perceived vulnerability of the refugee camp, which I argue is in part determined by the demographic make-up of the camp.

First, the benefits to an outside armed group attacking a refugee camp directly relate to the goals driving the armed group to take action. If the focus is economic via looting, then the refugee camps must possess enough material resources to plunder to offset the physical and economic cost of an attack. If the goal is forced recruitment, then there needs to be appropriate types of refugees to conscript (e.g. not too young or too old). If the end goal is politicide or genocide, then merely killing refugees provides the benefit. 


\section{Richard A. I. Johnson}

However, the goal of an attack may not come from any single issue, but a combination of these reasons. For any of the goals listed above, the cost of an attack also plays a role in decision-making.

Second, the vulnerability of the refugee camp greatly affects the cost of attack. A camp with efficient protection increases the cost of attack because there is increased resistance against an attacking force. Similarly, the costs associated with attack decrease when a camp is protected by a small or unmotivated force. At the extreme, when the host government supports the attacking group, the costs greatly decrease; this occurred in 2000 when Liberian forces forcibly recruited from refugee camps in Guinea with Guinean governmental approval (Milner 2005). However, it is common knowledge in the aid community that refugee camps often do not receive adequate physical security from host states (UNSC 1998; Achvarina and Reich 2006). Thus, I examine other demographic factors that affect the vulnerability of refugee camps.

\section{Hypotheses}

To develop a comprehensive model determining the vulnerability of refugee camps, the model must account for factors affecting both opportunity and willingness of the groups suffering from the forces of lateral pressure. However, the available data on individual refugee camps prevents the testing of opportunity factors affecting the decision-making process. Therefore, this study focuses exclusively on willingness factors that affect the vulnerability of a refugee camp to attack. ${ }^{2}$

A camp's vulnerability affects the degree to which the camp is an attractive target for armed groups to attack. The more vulnerable a refugee camp, the more likely it is to be attacked: when a camp is vulnerable, the willingness of armed groups to attack the camp increases because the cost is low. Therefore, in order to determine the likelihood of an attack, I need to measure camp vulnerability. One way to do so is to look at the demographic make-up of the camps. For example, refugee camps with a high percentage of male residents should be subject to lower probabilities of attack. Here, the logic is that male refugees are more likely to take up arms than female refugees (Lischer 2005), which, in turn, decreases the camp's overall vulnerability. Hence, the higher proportion of males within the camp tempers the willingness of outside groups to an attack a camp due to a cost increase.

Hypothesis 1: The higher the proportion of males residing in a camp, the lower the likelihood of an attack on the camp. ${ }^{3}$

In addition to the gender distribution of the camp, the age distribution also plays an important role in vulnerability. A concentration of younger individuals creates a prime target for armed groups seeking to recruit new members forcibly (Reich 2008). In addition, camps with more young refugees are increasingly vulnerable to attack due to a potential lack of an adult population 
for adequate defence. The low cost from the potential easiness of victory, due to the high vulnerability of children, increases the willingness for attacks on camps.

Hypothesis 2: The higher the level of young refugees, the higher the likelihood of an attack on the camp.

Finally, the overall size of the camps is a factor of vulnerability that may lead to attack by outside groups (UNHCR 1999; Reich 2008). Intuitively, as camps become larger, they should become less vulnerable, if we assume that larger camps have larger security forces. However, in reality host states are often unable or unwilling to provide adequate physical security for refugee camps (UNSC 1998; Achvarina and Reich 2006). Thus, as camps increase in size the security force assigned for protection may remain the same, causing a lower refugee-security ratio. The lack of adequate camp security, combined with the larger size of camps, increases the vulnerability of refugees, which means larger camps should be more prone to attack. There are higher levels of material resources to loot and proportionally fewer security guards to protect the material resources.

Hypothesis 3: The larger the camp, the greater the likelihood of an attack.

\section{Alternative Hypotheses}

While I argue demographic factors affect the vulnerability of refugee camps, other alternative hypotheses can be drawn from previous literature. Drawing from the work of Weinstein (2005, 2007), Humphreys (2005), and Humphreys and Weinstein (2006) relating to rebel groups and civilian treatment, I put forth two alternative hypotheses that relate to refugee camp vulnerability. The first is ongoing conflict in the host state where the camp is located or the home state the refugees fled. The logic is that the presence of conflict in either state means there are armed groups in need of material resources or combatants; refugee camps possess both. If no conflict is occurring in the host state, the government may be willing to assign additional physical security to camps in order to enhance stability. If no conflict is occurring in the home state of refugees, the need for armed groups to move beyond their borders decreases.

Alternative Hypothesis 1: Ongoing conflict in the host or home state will increase the likelihood of an attack on a refugee camp.

Second, armed groups have alternative options for funding if the host or home state possesses lootable resources. Weinstein (2007) argues rebel groups with access to lootable resources are economically endowed, which means they can use indiscriminate violence against civilians. For refugee camps, the implication is that if local armed groups attack camps, the 


\section{Richard A. I. Johnson}

motivation is unlikely to be resource gain. Across the border, if the home state of the refugees possesses lootable resources, armed groups may not want to exert the effort to engage in cross-border action, with the exception being for the purpose of politicide or genocide. However, it can be difficult to determine where the armed group that attacks a refugee camp originates.

Alternative Hypothesis 2a: The presence of lootable resources in the HOST state will increase the likelihood of an attack on a refugee camp.

Alternative Hypothesis 2b: The presence of lootable resources in the HOME state will decrease the likelihood of an attack on a refugee camp.

\section{Data and Test}

To test the hypotheses, I use a binomial logit. Due to the limited nature of the data and time restrictions for hand coding, I limit the scope to the African continent. I focus on Africa because it has the highest levels of armed attacks on camps in the world (Muggah and Mogire 2006). I collect data for the dependent variable on the occurrence of armed attacks on refugee camps using media content analysis. For the independent variables, I use camp level data from UNHCR (2008).

The dependent variable is armed attacks on refugee camps between 2006 and 2008. I determine the occurrence of an armed attack by doing media content analyses. The primary, though not the only, sources for the analysis are UNHCR, Reuters, and the Associated Press. Previous research shows that examination of media sources is appropriate to determine the occurrence of an event (Achvarina and Reich 2006; Eck and Hultman 2007; Gartner 2004). Each source was read to determine if any of the refugee camp militarization (armed attack) classifications put forth by Muggah and Mogire (2006) are present (i.e. armed violence in camps, political activism and violence, storage and trafficking of small arms, military training and recruitment, infiltration of armed elements, use of relief/development resources). If any of the characteristics are present, I code the case as '1'; those camps with no reports of attack are coded as ' 0 '. I drop refugee camps returning zero results in the content analysis. Out of 198 camps, 98 camps are included in the dataset over the course of three years, resulting in an $\mathrm{N}$ of 220 . I find that an attack or forced recruitment occurred in 9.5 per cent of refugee camps in Africa.

The UNHCR statistical database provides the data for the main independent variables. The database provides camp level demographic data between 2006 and 2008, which includes population, age, and gender breakdowns. Though armed groups that attack refugee camps will not know the exact demographics, they should have an idea of the general make-up of the camp. Four independent variables are included in the model: percentage of male refugees, the percentage of the camp between the ages of 5 and 11, the 
Table 1

\begin{tabular}{lcc}
\hline Summary Statistics & & \\
\hline Variable & Mean (Median) & Standard Deviation \\
\hline Percentage Male & 48.972 & 5.911 \\
Percentage 5-11 & 21.936 & 6.736 \\
Percentage 12-17 & 15.655 & 4.992 \\
Population (Logged) & 9.046 & 1.229 \\
Population & 15057 & 16209 \\
Host Conflict & $(1)$ & \\
Home Conflict & $(1)$ & \\
Lootable Resources, Host & $(0)$ & \\
Lootable Resources, Home & $(0)$ & \\
\hline
\end{tabular}

percentage of the camp between the ages of 12 and 17, and the log of the population. I use two age groups to model the relationship between age and perceived vulnerability. I include the selection of ages 5 to 11 because, at that age, children are capable of acting on their own without as much reliance on adults to take actions such as running and hiding. The group is separate from the 12 to 17 age group due to the older refugee children being capable participants in the defence of the refugee camp, but also being of a desirable age for forced recruitment.

To model the two alternative hypotheses, I include two control variables in each model. The first set is the presence of conflict in the host state and the home state of the refugees according to the Geneva Declaration Secretariat's (2008) report. The second set is the presence of lootable resources (tropical timber or alluvial diamonds, as classified by Snyder 2006) in the host state and the home state of the refugees. A single interaction model cannot be used because states suffering from conflict do not possess lootable resources in the time period examined. However, the combination of conflict and lootable resources witnessed in the time period studied is historically unrepresentative (see Weinstein 2007). Table 1 presents the summary statistics.

\section{Results}

For both models, the results of the binary logit support the use of demographic indicators as predictors of vulnerability and overall refugee camp security. For each model, I will go through the results in relation to the hypotheses put forth. In order to put the results in a more interpretable context, I then present graphs showing the predicted probability of an attack on a refugee camp, while varying the levels of significant demographic characteristics of the camps. These findings highlight the importance of considering refugee camp demographics in order to enhance security. In addition, 
Table 2

Binary Logit Results of Refugee Camp Demographics Effect on Armed Attacks

\begin{tabular}{lcc}
\hline Variable & Coefficient & Robust Standard Error \\
\hline Percentage Male & $-0.203^{*}$ & 0.102 \\
Percentage 5-11 & 0.016 & 0.053 \\
Percentage 12-17 & $-0.283^{*}$ & 0.127 \\
Population (Logged) & 0.136 & 0.292 \\
Conflict (Host) & -0.237 & 0.821 \\
Conflict (Home) & 0.965 & 0.943 \\
\hline
\end{tabular}

Pseudo-Log Likelihood $=-49.446$.

Pseudo $\mathrm{R}^{2}=0.190$.

$\mathrm{N}=206$.

$*=$ p-value $<0.05$.

${ }^{\#}=$ p-value $<0.10$.

the significance of demographic variables shows that additional data collection is necessary to investigate the issue further.

\section{Conflict Control Model}

Table 2 presents the results of the binary logit on the effect of demographic characteristics on the likelihood of an armed attack using the conflict control variables. The results show the gender variable is statistically significant with a coefficient of -0.203 , supporting Hypothesis 1 . In addition, the age 12-17 variable is statistically significant with a coefficient of -0.283 . However, the age variables sign is in the opposite direction than Hypothesis 2 predicts. The implication is that as the population of refugees between the ages of 12 and 17 increases, there is a decrease in the likelihood of an attack on a camp. The results for Hypothesis 2 for ages 12 to 17 suggest that this group of refugees possesses some level of deterrence for armed groups. Hypothesis 3, the size of population of refugee camps, does not receive support in this model. The alternative hypothesis of conflict does not receive support either. ${ }^{4}$ The presence of conflict is not a significant predictor of an attack when demographic factors are entered into the model.

Figure 1 helps us visualize the significant demographic variables in the model controlling for conflict in the host or home state. The graph varying the percentage of males within a refugee camp shows that as the level of males increases, the predicted probability of attack decreases, as do the 95 per cent confidence intervals. This result supports Hypothesis 1, where the likelihood of an attack moves drastically towards zero after the percentage male crosses 55 per cent. The graph visualizing varying levels of teenage refugees in a camp does not correspond with Hypothesis 2, as stated above; however, the variable is significant. The second graph shows that as the level of 12 to 
Figure 1

Predicted Probabilities of an Attack on Refugee Camps: Varying Demographics
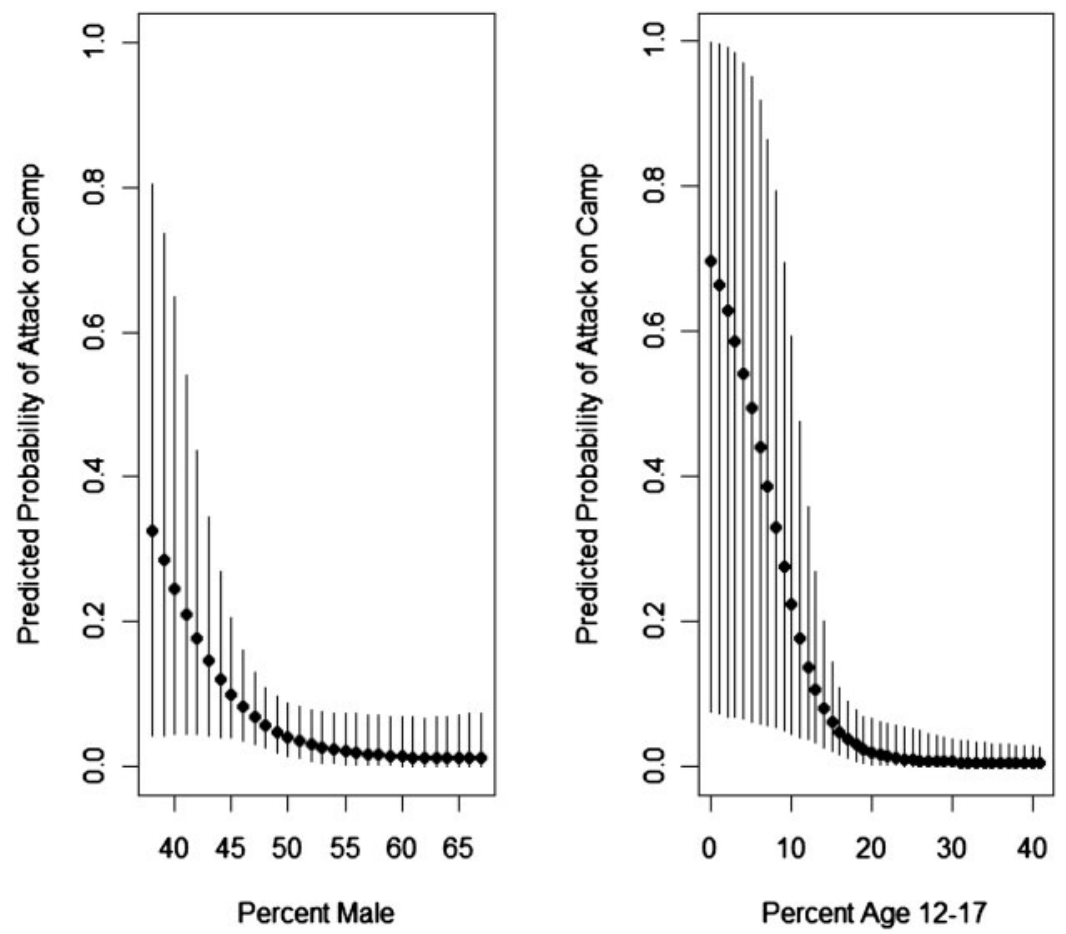

17 year-olds increases, the probability of an attack decreases. The likelihood bottoms out and remains constant, with small confidence intervals, as the percentage of teenagers passes 20 per cent. The predicted probabilities for the lootable resources model produce similar results, but I discuss it separately because the two models coefficients are not directly comparable.

\section{Lootable Resources Control Model}

Table 3 presents the results of another binomial logit using the presence of lootable resources as the alternative hypothesis. The gender variable, for Hypothesis 1 , has a p-value of 0.06 , making it marginally statistically significant with a coefficient -0.261 . An increase in the levels of males in refugee camps decreases the likelihood of an attack. The age 12-17 is statistically significant with a coefficient of -0.218 , but consistent with the previous model, the significant age variable's sign is in the opposite direction than Hypothesis 2 predicts. Hypothesis 3 receives support with the logged population variable having a coefficient of 0.608 . The alternative hypothesis 
Table 3

Binary Logit Results of Refugee Camp Demographics Effect on Armed Attacks

\begin{tabular}{lcc}
\hline Variable & Coefficient & $\begin{array}{c}\text { Robust Standard } \\
\text { Error }\end{array}$ \\
\hline Percentage Male & $-0.261^{* *}$ & 0.141 \\
Percentage 5-11 & 0.018 & 0.077 \\
Percentage 12-17 & $-0.218^{*}$ & 0.110 \\
Population (Logged) & $0.608^{*}$ & 0.195 \\
Lootable Resources (Host) & $4.465^{*}$ & 0.571 \\
Lootable Resources (Home) & $-3.167^{*}$ & 0.601 \\
\hline
\end{tabular}

Pseudo-Log Likelihood $=-40.933$.

Pseudo $\mathrm{R}^{2}=0.330$.

$\mathrm{N}=206$.

$*=$ p-value $<0.05$.

${ }^{\#}=$ p-value $<0.10$.

receives support from both control variables, indicating that the presence of lootable resources in the host and home countries affects the likelihood of an attack, with coefficients of 4.465 and -3.167 , respectively. Though the presence of lootable resources is statistically significant in the model, the substantive significance of these variables is not as powerful as the main independent variables.

Figure 2 presents the predicted probabilities, with 95 per cent confidence intervals, of an attack on a refugee camp when varying the significant demographic variables. The first graph visualizing Hypothesis 1, varying the percentage of males in the refugee camp, shows that as the male population of a camp increases, the likelihood of an attack decreases. In addition, the 95 per cent confidence interval drastically shrinks and remains somewhat constant after the percentage of males within the camp increases past 50 per cent. The percentage of teenagers within a camp produces an interesting result, which does not support Hypothesis 2, as stated. As the percentage of refugees aged 12-17 increases, the likelihood of attack decreases quickly, along with the confidence intervals. However, after the percentage passes 20 per cent, the likelihood of an attack begin to increase, albeit slightly, while the confidence intervals enlarge. The third graph visualizes Hypothesis 3, showing that as population increases, so does the likelihood of an attack, which is consistent with the literature (UNHCR 1999; Reich 2008). However, over the range of refugee camp size, the probability of an attack does not drastically increase, suggesting the UNHCR recommendation for camp size may not be as important as thought. The graphs presented for both models show that shifting the demographics in refugee camps can lower the probability of an attack.

Overall, the results support the argument that varying the demographic makeup of refugee camps can reduce the likelihood of an attack. At a 
Figure 2

Predicted Demographics
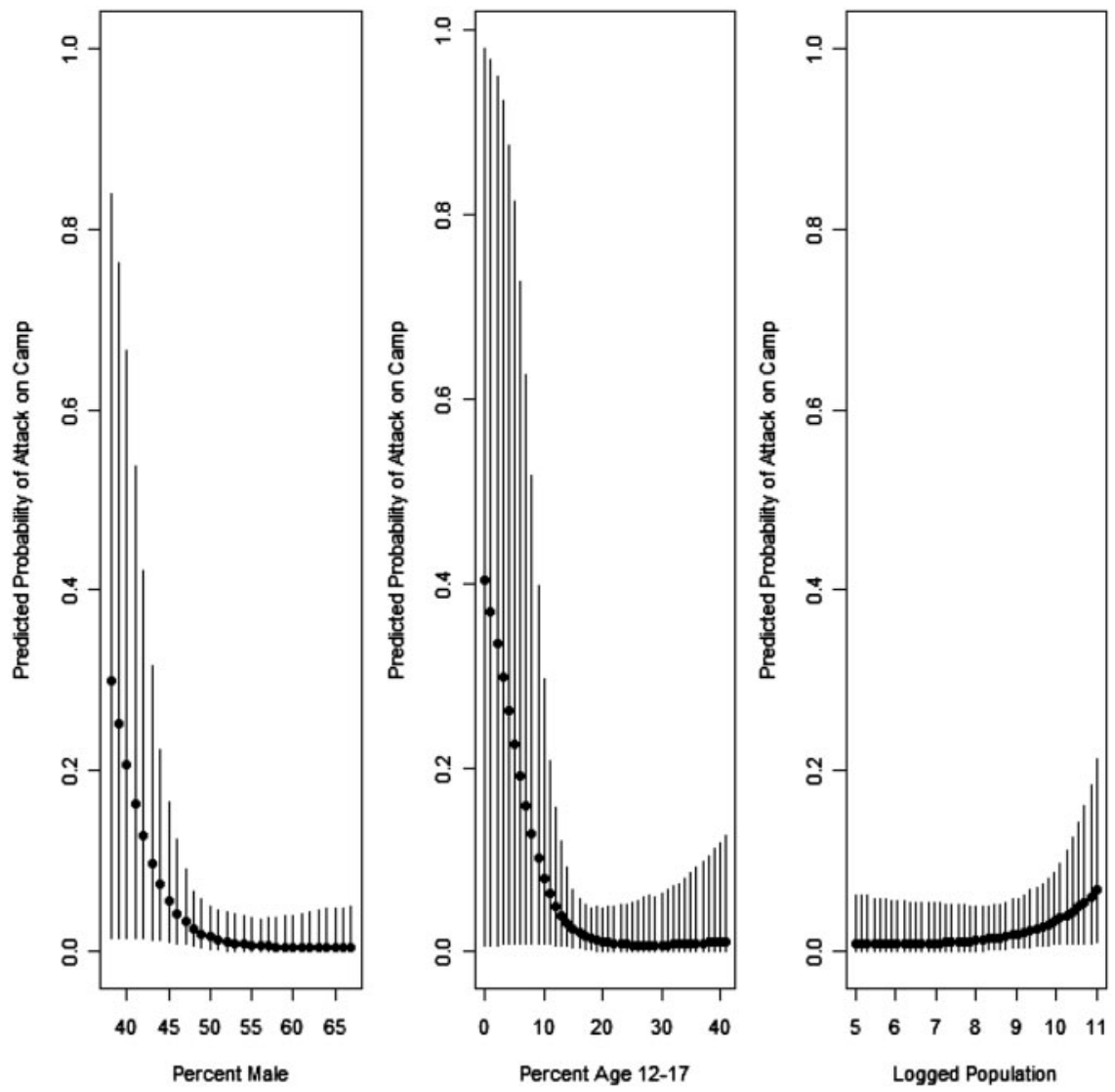

minimum, the findings should encourage additional research and data collection on camp level characteristics. In addition, collection of more detailed data on armed attacks on camps could allow for more specific theories and findings. In the next section, I discuss the implications of the results in more detail and identify the types of data that need collection.

\section{Discussion}

The results of both tests indicate the demographic profile of refugee camps needs to be taken into account in relation to refugee camp security. One option is to conduct demographic engineering to create safer camps. The 
distribution of refugees to various camps can take place at transfer centres near the borders in order to make up well-balanced camps. I am not suggesting adjusting the demographic profile of camps will be easy, but rather that it should be done to the best of the ability of those involved in order to create an environment where refugees are less vulnerable. Any steps that can be taken to promote refugee security should be taken, especially since host states are not providing adequate physical security in most cases. When compared to the physical cost of guarding camps, adjusting demographics may be less expensive than private security while allowing aid groups to remain neutral.

Alternatives to demographic engineering exist in those countries where the government is willing to provide security, but does not possess proper funding. One option is to use demographic analysis to determine the ideal assignment of scare security forces. Efficient assignment of effective security forces can reduce the willingness of armed groups to attack refugee camps. In addition, if the allocation of limited security resources is successful, other host governments may be willing to follow suit and begin providing security for refugee camps. For the time being, refugee camps remain vulnerable and should be a focus for researchers seeking to minimize refugee vulnerability in any way possible. In other words, no uniform policy options exist for all refugee camps, the involvement of the host state in the security process will dictate what actions can be taken to reduce refugee vulnerability; however, the full impact of demographics on vulnerability requires additional data collection.

The focus on vulnerability, through the willingness of armed groups, though, is not complete. Additional factors for which data are not easily available exist. First, the origin of the refugees may matter to the armed groups attacking the camps, depending on their goals. Camps of state-in-exile refugees may not be a desirable target to groups seeking material resources due to the organization of the refugees (see Lischer 2003), but could be a desirable target to groups whose goal is politicide or genocide. Second, the level of security present at the camp can affect the willingness of armed groups. Despite knowing that by-and-large refugee camps lack physical security provided by host states, additional knowledge can be gained from categorizing the level of security at various camps. Any additional data on camp level characteristics will help to model fully the vulnerability of refugee camps, since host governments are unlikely to increase physical security funding.

Beyond the willingness factors tested in this paper, a complete model of camp vulnerability requires the inclusion of opportunity factors. The incorporation of opportunity factors is important because a primary way of lowering willingness is to reduce the opportunity for attacks to take place. The distance of the refugee camp from the border directly affects opportunity. A camp located near the border increases the opportunity for armed attacks (Reich 2008; UNSC 1998). From the view of outside forces, attacking the camp is easier the closer the camp is to the border, which may encourage 
attacks due to the ability to gain material resources and an increase in the perception of vulnerability. Data need to be collected on where exactly camps are located and the distance of the camps from the border by both road and direct route over land; currently the Ford Foundation for Human Security is investigating these factors.

\section{Conclusion}

This article presents a preliminary investigation of the determinants of the vulnerability of refugee camps based on demographics. Using a theory of lateral pressure with an opportunity and willingness framework, I find the demographic profile of refugee camps provides some explanation of whether or not an attack on a camp by an armed group will occur. In particular, the distribution of males versus females, the level of teenage refugees within the camp, and the overall population size affect the likelihood of an attack. Due to the high cost of providing physical security, many host states cannot or will not provide adequate forces; thus, as the size of the camps increases so does the likelihood of attack or forced recruitment. However, as the percentage of males within the camps increases, the likelihood of an attack or forced recruitment decreases. In turn, changing the age distribution of refugees within the camps to a lower level decreases the likelihood of an attack. These findings suggest that policymakers should take the demographic make-up of camps into account at transfer centres in order to provide optimal physical security at a reasonable cost, since host countries may not be willing or able to provide comprehensive security.

In conclusion, refugees facing any type of attack or militarization suffer in an extremely dangerous situation, which may be relieved with additional research that translates into policy change. Refugees have a right to physical and human security, but proper funding is often unavailable and is not likely to be available any time soon. Thus, when refugee camps become necessary, and organizers are determining camp logistics, they should consider demographics. For example, a one-time cost of transporting refugees farther away from the border is likely far less expensive than trying to find funding for higher levels of physical and human security in a camp close to the border or repaying sunk costs if a future move is necessary. In the end, correctly understanding the causes of attacks on refugee camps is critical to providing long-term security for this fragile group.

\section{Acknowledgements}

Previous versions of this project were presented at the 2009 annual meeting of the International Studies Association and 2008 annual meeting of the International Studies Association: West. I would also like to thank Caitlin Milazzo, Jeannette Money, Sherry Zaks, and two anonymous reviewers for invaluable support and suggestions. Any remaining errors are my own. 


\section{Richard A. I. Johnson}

1. Weinstein (2007) briefly discusses recruitment styles and payment abilities that result in armed groups being classified as bandits as opposed to rebels.

2. In a later section, I discuss the opportunity factors necessary for a complete study, along with some additional willingness factors that should be taken into account.

3. Hypothesis 1 highlights the necessity for studying both militarized refugees and camp militarization. A decrease in the likelihood of one type of militarization may lead to an increase in the other, which indicates organizers need to take into account the optimal male population in order to maximize security from forces inside and out (see Lischer 2005).

4. Alternative models measuring the length of the conflict in the host and/or home state to show protracted refugee situations did not receive significant results either. Demographic variables remained the same statistically.

ACHVARINA, V. and REICH, S. F. (2006) 'No Place to Hide: Refugees, Displaced Persons, and the Recruitment of Child Soldiers'. International Security 31: 127-164.

ADAMSON, F. (2006) 'Crossing Borders: International Migration and National Security'. International Security 31: 165-199.

AFRICAN DEVELOPMENT BANK (2009) African Development Report. Oxford: Oxford University Press.

ALFREDSON, L. (2002) 'Child Soldiers, Displacements and Human Security'. Disarmament Forum 2002(3): 17-27.

BARNETT, L. (2002) 'Global Governance and the Evolution of the International Refugee Regime'. International Journal of Refugee Law 14: 238-262.

BLACK, R. (1998) Refugees, Environment and Development. New York: Longman.

BLACK, R. (2001) 'Fifty Years of Refugee Studies: From Theory to Policy'. International Migration Review 35: 57-78.

BLAVO, E. Q. (1999) The Problems of Refugees in Africa: Boundaries and Borders. Brookfield: Vermont, Ashgate.

CARIK, D. S. (2008) Porous Borders and the Insecurity of Civilians: Cross-border Violence in Darfur and Eastern Chad. Pittsburgh: Ford Institute for Human Security.

CHOUCRI, N. and NORTH, R. C. (1975) Nations in Conflict: National Growth and International Violence. San Francisco: WH Freeman and Company.

CRISP, J. (2003) 'No Solutions in Sight: the Problem of Protracted Refugee Situations in Africa'. Refugee Survey Quarterly 22: 114-150.

ECK, K. and HULTMAN, L. (2007) 'One-Sided Violence Against Civilians in War: Insights from New Fatality Data'. Journal of Peace Research 44: 233-246.

FEIN, H. (1993) 'Accounting for Genocide after 1945: Theories and Some Findings'. International Journal of Group Rights 1: 79-106.

FERRIS, E. G. (1985) 'Refugees and World Politics: Overview'. In Ferris, E. G. (ed.) Refugees and World Politics. New York: Praeger.

GARTNER, S. S. (2004) 'Making the International Local: The Terrorist Attack on the USS Cole, Local Casualties, and Media Coverage'. Political Communication 21: 139-159.

GENEVA DECLARATION SECRETARIAT (2008) The Global Burden of Armed Violence. Geneva: GD Secretariat.

GOLDSTONE, J. A. (2001) 'Demography, Environment, and Security'. In Diehl, P. and Gleditsch, N. P. (eds) Environmental Conflict. Boulder, CO: Westview Press.

GORMAN, R. F. (1987) Coping with Africa's Refugee Burden: A Time for Solutions, Dordrecht, Netherlands, Martinus Nijhoff.

HAMMERSTAD, A. (2000) 'Whose Security?: UNHCR, Refugee Protection and State Security After the Cold War'. Security Dialogue 31: 391-403. 
HARFF, B. and GURR, T. R. (1988) 'Toward Empirical Theory of Genocides and Politicides: Identification and Measurement of Cases since 1945'. International Studies Quarterly 32: 359-371.

HOMER-DIXON, T. F. (1994) 'Environmental Scarcities and Violent Conflict: Evidence from Cases'. International Security 19: 5-40.

HUMPHREYS, M. (2005) 'Natural Resources, Conflict, and Conflict Resolution: Uncovering the Mechanisms'. Journal of Conflict Resolution 49: 508-537.

HUMPHREYS, M. and WEINSTEIN, J. M. (2006) 'Handling and Manhandling Civilians in Civil War'. American Political Science Review 100: 429-447.

JACOBSEN, K. (2002) 'Can Refugees Benefit the State? Refugee Resources and African Statebuilding'. Journal of Modern African Studies 40: 577-596.

LISCHER, S. K. (2003) 'Collateral Damage: Humanitarian Assistance as a Cause of Conflict'. International Security 28: 79-109.

MANDEL, R. (1997) 'Perceived Security Threat and the Global Refugee Crisis'. Armed Forces and Society 24: $77-103$.

LISCHER, S. K. (2005) Dangerous Sanctuaries: Refugee Camps, Civil War, and the Dilemmas of Humanitarian Aid. New York: Cornell University Press.

MARTIN, A. (2005) 'Environmental Conflict Between Refugee and Host Communities'. Journal of Peace Research 42: 329-346.

METCALFE, G. (1970) 'Effects of Refugees on the National State'. In Brooks, H. and El-Ayouty, Y. (eds) Refugees South of the Sahara: An African Dilemma. Westport, Connecticut: Negro Universities Press.

MILNER, J. (2005) 'The Militarization and Demilitarization of Refugee Camps in Guinea'. In Florquin, N. and Berman, E. G. (eds) Armed and Aimless: Armed Groups, Guns, and Human Security in the ECOWAS Region. Geneva: Small Arms Survey.

MOST, B. A. and STARR, H. (1989) Inquiry, Logic, and International Politics. Columbia: University of South Carolina Press.

MTANGO, E.-E. (1989) 'Military and Armed Attacks on Refugee Camps'. In Loescher, G. and Monahan, L. (eds) Refugees and International Relations. New York: Oxford University Press.

MUGGAH, R. and MOGIRE, E. (2006) 'Arms Availability and Refugee Militarization in Africa: Conceptualizing the Issue'. In Muggah, R. (ed.) No Refuge: The Crisis of Refugee Militarization in Africa. London: Zed Books.

PITTERMAN, S. (1985) 'International Responses to Refugee Situations: the United Nations High Commissioner for Refugees'. In Ferris, E. G. (ed.) Refugees and World Politics. New York: Praeger.

REICH, S. (2008) What Makes a Camp Safe?. Pittsburgh: Ford Institute for Human Security.

ROGGE, J. R. (1981) 'Africa's Resettlement Strategies'. International Migration Review 15: $195-212$.

ROSS, M. L. (2004) 'What Do We Know about Natural Resources and Civil War?' Journal of Peace Research 41: 337-356.

SIVERSON, R. M. and STARR, H. (1990) 'Opportunity, Willingness and the Diffusion of War, 1816-1965'. American Political Science Review 84: 47-67.

SIVERSON, R. M. and STARR, H. (1991) The Diffusion of War: A Study of Opportunity and Willingness. Ann Arbor: University of Michigan Press.

SNYDER, R. (2006) 'Does Lootable Wealth Breed Disorder? A Political Economy of Extraction Framework'. Comparative Political Studies 39: 943-968.

STEDMAN, S. J. (2003) 'Conclusion and Policy Recommendations'. In Stedman, S. J. and Tanner, F. (eds) Refugee Manipulation: War, Politics, and the Abuse of Human Suffering. Washington DC: Brookings Institution.

STEIN, B. N. (1986) 'Durable Solutions for Developing Country Refugees'. International Migration Review 20: 264-282. 


\section{Richard A. I. Johnson}

TÜRK, V. (2003) 'Forced Migration and Security'. International Journal of Refugee Law 15: $114-125$.

UNDP (1994) Human Development Report. Oxford: Oxford University Press.

UNHCR (1999) 'The Security, and Civilian and Humanitarian Character of Refugee Camps and Settlements', EC/49/SC/INF.2, available at: http://www.unhcr.org/refworld/docid/ 4a54bc04d.html [accessed 29 November 2010].

UNHCR (2008) 'UNHCR Statistical Online Population Database', www.unhcr.org/statistics/ populationdatabase.

UNHCR (2000) The Security, Civilian and Humanitarian Character of Refugee Camps and Settlements: Operationalizing the 'Ladder of Options', EC/50/SC/INF.4, available at: http:// www.unhcr.org/refworld/docid/4a54bc040.html [accessed 29 November 2010].

UNSC (1998) 'UN Security Council Resolution 1208 (1998) on the Situation in Africa: Refugee Camps', http://daccess-dds-ny.un.org/doc/UNDOC/GEN/N98/362/90/PDF/ N9836290.pdf?OpenElement.

URDAL, H. (2005) 'People vs Malthus: Population Pressure, Environmental Degradation, and Armed Conflict Revisited'. Journal of Peace Research 42: 417-434.

WCED (World Commission on Environment and Development) (1987) Our Common Future. New York: Oxford University Press.

WEINSTEIN, J. M. (2005) 'Resources and the Information Problem in Rebel Recruitment'. Journal of Conflict Resolution 49: 598-624.

WEINSTEIN, J. M. (2007) Inside Rebellion: The Politics of Insurgent Violence. Cambridge: Cambridge University Press. 